\title{
The secret identities of TMPRSS2: Fertility factor, virus trafficker, inflammation moderator, prostate protector and tumor suppressor
}

\author{
Richard J. Epstein ${ }^{\mathrm{a}, \mathrm{b}, *}$ \\ ${ }^{a}$ New Hope Cancer Center, Beijing United Hospital, Jiangtai Xi Rd 9-11, Chaoyang, \\ Beijing, China \\ ${ }^{\mathrm{b}}$ Garvan Institute of Medical Research, and UNSW Medical School, St Vincent's Hospital, \\ Victoria St, Darlinghurst, Sydney, Australia
}

Received 1 April 2021

Accepted 11 June 2021

\begin{abstract}
The human TMPRSS2 gene is pathogenetically implicated in both coronaviral lung infection and prostate cancer, suggesting its potential as a drug target in both contexts. SARS-COV-2 spike polypeptides are primed by the host transmembrane TMPRSS2 protease, triggering virus fusion with epithelial cell membranes followed by an endocytotic internalisation process that bypasses normal endosomal activation of cathepsin-mediated innate immunity; viral co-opting of TMPRSS2 thus favors microbial survivability by attenuating host inflammatory responses. In contrast, most early hormone-dependent prostate cancers express TMPRSS2:ERG fusion genes arising from deletions that eliminate the TMPRSS2 coding region while juxtaposing its androgen-inducible promoter and the open reading frame of $E R G$, upregulating pro-inflammatory $E R G$ while functionally disabling TMPRSS2. Moreover, inflammatory oxidative DNA damage selects for TMPRSS2:ERG-fused cancers, whereas patients treated with antiinflammatory drugs develop fewer of these fusion-dependent tumors. These findings imply that TMPRSS2 protects the prostate by enabling endosomal bypass of pathogens which could otherwise trigger inflammation-induced DNA damage that predisposes to TMPRSS2:ERG fusions. Hence, the high oncogenic selectability of TMPRSS2:ERG fusions may reflect a unique pro-inflammatory synergy between androgenic $E R G$ gain-of-function and fusogenic TMPRSS2 loss-of-function, cautioning against the use of TMPRSS2-inhibitory drugs to prevent or treat early prostate cancer.
\end{abstract}

Keywords: Prostate cancer, host defense, proteases, inflammation, innate immunity, SARS-COV-2, COVID-19

\section{Introduction}

Of the twenty thousand genes in the human genome, one has gained recent recognition for two distinct reasons: transmembrane serine protease 2 (TMPRSS2) is one of two key genes encoding membrane proteins that mediate infectivity of the COVID-19 coronavirus (CV) SARS-COV-2, whilst also being one of two (fused) genes implicated in $50 \%$ of primary prostate cancers [1-3]. Is this a coincidence, or could there be a function of the TMPRSS2 gene product that accounts for its involvement in both pathogenetic contexts?

\footnotetext{
${ }^{*}$ Corresponding author: Richard J. Epstein, Tel. :+86 105927 7008; E-mail: Richard.Epstein@ufh.com.cn. ORCID: 0000-0002-4640-0195 
Two percent of human genes encode proteases, the functions of which remain incompletely understood; part of this interpretational difficulty lies in the cascade-like feedback interactions between proteases and their substrates $[4,5]$ which hamper clarifying the role of any single protease-encoding gene. Examples include androgen-inducible kallikrein-related peptidases in seminal fluid such as KLK2 and prostate-specific antigen (PSA), which have been implicated as either tumor-suppressive or oncogenic in different contexts [6-9]. The TMPRSS2 gene on chromosome 21q22.3 encodes another androgen-inducible serine protease found in semen; this gene is most highly expressed in the adult prostate [10], and at lower levels in the gut, breast, ovary, kidney, heart and lung [11, 12], in which latter organ it is targeted by SARS-COV-2 [13]. Some research, though not all [14], has raised hopes about the value of androgen-deprivation therapy for blocking lung TMPRSS2 expression and thus reducing SARS-COV-2 infectivity [3, 15-19], while similar interest has focused on using TMPRSS2 inhibitors to prevent or treat this infection [20].

The frequent involvement of TMPRSS2 in prostate cancer gene fusions [21] has likewise led to suggestions that oral drug inhibitors of the TMPRSS2 protease may benefit patients with, or at risk of, this disease [10, 12, 22, 23]. The hypothesis of TMPRSS2 being an actionable driver of prostate cancer [24] has also received support from preclinical models [22, 25]. Here this thesis is revisited in the light of recent cross-disciplinary insights from SARS-COV-2-related research.

\section{TMPRSS2 structure and function}

TMPRSS2 encodes a type II transmembrane serine protease (TTSP) that includes three adjacent extracellular domains - the juxtamembrane LDL receptor A (LDLRA) domain, an intermediary scavenger receptor cysteine-rich (SRCR) domain, and a carboxyterminal serine protease (SP) domain which modular structure is tightly conserved across phylogeny [26], even extending to invertebrates [1] (Fig. 1A). In addition, human TMPRSS2 expression varies markedly between fetal and adult life in a bidirectional and tissue-dependent manner [26] (Table 1). These findings imply that TMPRSS2 serves an important, albeit not yet sharply defined, biologic function.

The extracellular location of the tripartite LDLRA-SRCR-SP cassette suggests a transmembrane signaling function, such as proteolytic activation of extracellular matrix proteins [22] or growth factors [25], and/or a defense function targeting extrinsic pathogens, as suggested by the role of TMPRSS2 in SARS-COV-2 infection [27] (see below). Mutagenesis studies have shown that the SRCR domain adjacent to the SP domain is essential for TMPRSS2 catalytic activity, whereas the LDLRA domain is dispensable [28]. Evolutionary conservation of the SRCR domain is consistent with, but does not prove, an affinity for microbial polyanionic molecules including proteins, lipopolysaccharides - which activate other proteases implicated in prostate cancer invasion [29] - or polynucleotides [30]. Another androgeninducible serine protease, PSA, has been implicated in prostatic innate defence [31], consistent with PSA rises associated with either microbial [32] or non-microbial [33, 34] prostatic inflammation.

TMPRSS2 is synthesized as a latent zymogen which is first expressed as an intact 58-70 kDa transmembrane protein, but may later undergo autocatalytic secretion into apical glandular lumina as the 32-42 kDa carboxyterminal SP domain [10, 35] (Fig. 1B). Both the androgen-inducibility and immunohistochemical location of the latter process suggest a proteolytic role for TMPRSS2 in semen [35]. This raises further questions: is autocatalytic cleavage and secretion of the SP fragment confined to prostatic tissues? Does androgen-dependent TMPRSS2 activation occur due to overexpression [10], with the protein's unpaired extracellular cysteine-140 in the SP domain [35] enabling disulfide bond formation between adjacent protease moieties, facilitating enzymatic cross-cleavage followed by secretion? If so, could this represent a mode of negative feedback on the sequelae of androgenic signaling, rather than simply a protease activation event? Does the transmembrane TMPRSS2 holoprotein containing the 


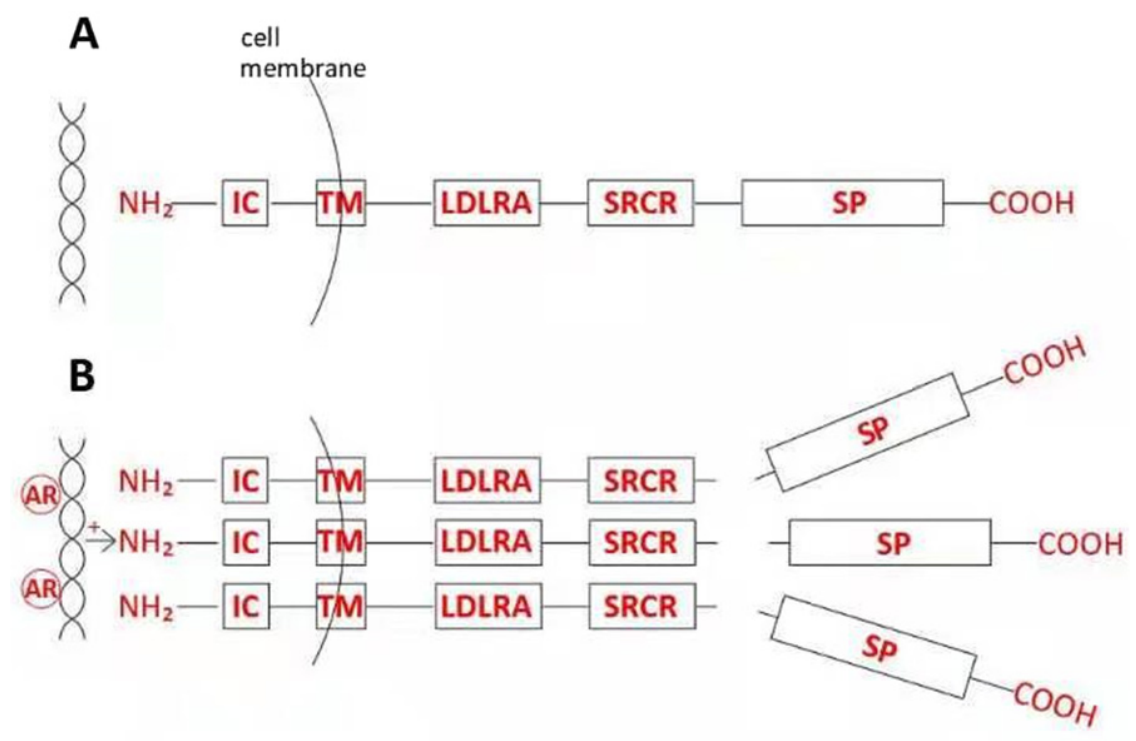

Fig. 1. Structure and posttranslational modification of prostatic TMPRSS2. A, The zymogen includes three adjacent extracellular subdomains, LDLRA, SRCR, and SP, in addition to transmembrane (TM) and a short intracellular (IC) domain. B, In response to androgen receptor (AR) stimulation, TMPRSS2 protein becomes overexpressed at the cell surface, followed by catalytic cleavage and secretion of proteolytically active SP domains into seminal fluid.

Table 1

Dynamic tissue-specific changes in TMPRSS2 mRNA expression levels ${ }^{1}$

\begin{tabular}{llc}
\hline TMPRSS2 expression & Fetal & Adult \\
\hline Lung & +++ & + \\
Brain & $+/-$ & +++ \\
\hline
\end{tabular}

${ }^{1}$ As measured by Northern blotting, in human tissues sampled in fetal and adult life, per the cited study by Paoloni-Giacobino et al. [26]. Such contrasting changes of expression suggest conserved functional roles not expected of a gene exhibiting true evolutionary redundancy.

uncleaved SP domain exert a function distinct from that of the secreted SP fragment; and following SP cleavage, does the residual stem LDLRA-SRCR-containing transmembrane protein retain a receptor function [10]? If so, does mislocalisation of transmembrane TMPRSS2 from apical cell membranes as reported with loss of cell polarity due to oxidative stress [36] or transformation [35, 37] - cause a change in protein function that could, in different contexts, either promote or inhibit tumorigenesis?

\section{TMPRSS2 as a fertility factor}

Pertinent to these knowledge gaps, TMPRSS3 is another TTSP containing an LDLRA-SRCR-SP cassette. Germline TMPRSS3 mutations affecting either the LDLRA or SRCR domains impair the proteolytic function of the SP domain via unknown mechanisms, with these non-SP mutations abolishing amiloride-sensitive sodium channel $(\mathrm{ENaC})$ function and thereby causing autosomal recessive nerve deafness [38]. Wild-type TMPRSS2 downregulates ENaC activity [39], opposing the normal effect of TMPRSS3; however, gene-targeted knockout mice lacking only the SP domain of TMPRSS2 appear viable, fertile, and without any abnormal phenotype [40]. Null mutations knocking out all domains 
of the TTSP matriptase gene - MT-SP1, which encodes a TMPRSS2 substrate [22] - are lethal [41]. Since sodium channel function is important for sperm fertility [42], and similar sperm-regulatory channelopathies cause male infertility [43], one possibility is that incomplete TMPRSS2 knockouts involving only SP domain loss are fertile due to compensatory retention of ENaC, analogous to hearing retention in pseudohypoaldosteronism patients who, like TMPRSS3 knockouts, have genetic loss of cochlear ENaC expression [44].

Another explanation beyond redundancy for the failure to demonstrate a TMPRSS2 knockout phenotype, even in whole-gene knockouts [45], is that a further stressor is needed to reveal the gene's function [46], with viral infection being one candidate. For example, the mumps paramyxovirus (MuV) is a common cause of orchitis and male sterility [47], such as could select for genes that prevent these outcomes. MuV increases its infectivity via inhibition of cytokine pathways mediating innate immunity [48], whereas other viruses including influenza and SARS-COV-2 evade the antiviral innate inflammatory responses by hijacking TMPRSS2 as an entry portal [49] (see below). Since TMPRSS2 is expressed in the testis together with its SARS-COV-2 co-receptor angiotensin-converting enzyme 2 (ACE2) [50, 51], and given that SARS-COV-2 viremia is often associated with mild orchitis [52], germline TMPRSS2 losses could predispose to more severe orchitis with higher risk of sterility. Moreover, since mumps (also known as epidemic parotitis) causes prominent salivary gland inflammation, and given that both TMPRSS2 and ACE2 are expressed in salivary glands [53], the possibility is raised by analogy that germline TMPRSS2 or ACE2 aberrations might affect fertility outcomes of orchitis caused not only by $\mathrm{CV}$ s but also by $\mathrm{MuV}$.

In common with TMPRSS2 - and hence plausibly related to their joint role in enabling extrinsic pathogens to bypass endosomal innate immunity (see below) - ACE2 expression is associated with reduced inflammation [54,55], although it is not yet clear whether this phenotype is independent of co-localised TMPRSS2 [56]. Against the latter possibility are reports that ACE2 activates inflammasomes on SARS-COV-2 binding [57], and that pro-inflammatory cytokines upregulate TMPRSS2 while downregulating ACE2 [58]. Nonetheless, since decreased expression of ACE2 also characterises Sertoli cells in patients with non-obstructive azoospermia [59], it seems possible that pre-existing $A C E 2$ defects could unmask TMPRSS2 hypofunction (e.g., due to heterozygous germline defects or promoter methylation) as a predisposition to infertility.

\section{TMPRSS2 as a virus trafficker}

New insights into the function of TMPRSS2 have been gained from its exploitation by RNA viruses, including influenza A - the hemagglutinin of which is cleaved by TMPRSS2 [60] - parainfluenza viruses [61], hepatitis C [62], and CVs such as SARS-COV-2; indeed, TMPRSS2 polymorphisms are reported to be predictors for the susceptibility and severity of such viral diseases [63]. The spike (S) proteins of SARS-COV-2 contain two TMPRSS2 cleavage sites, S1 and S2; proteolytic TMPRSS2 priming of S1 enables viral binding to human ACE2 receptors in bronchial secretory cells, then activation of S2 permits fusion of viral and cell membranes, allowing viruses entry to host cytoplasm [13]. Of note, the priming of S1 in this lung context implies that androgen-inducible catalytic cleavage and secretion is not essential for TMPRSS2 enzymatic activity; however, cells or organisms lacking TMPRSS2 are resistant to CVs [64], implying that the role of transmembrane TMPRSS2 in CV infection is indeed essential.

The evolutionarily deselected pathway of interest in this context appears to be endosomal endocytosis involving pathogen processing by intracellular cathepsins $\mathrm{B} / \mathrm{L}$, which is the entry pathway for CVs that infect cells lacking TMPRSS2 [65] (Fig. 2A). Consistent with this, TMPRSS2 inhibitors reduce CV pathogenicity whereas cathepsin inhibitors do not [66]. Since cathepsin-linked endosomes host Toll-like receptor (TLR) recognition proteins which mediate innate immunity [67], and given also that 

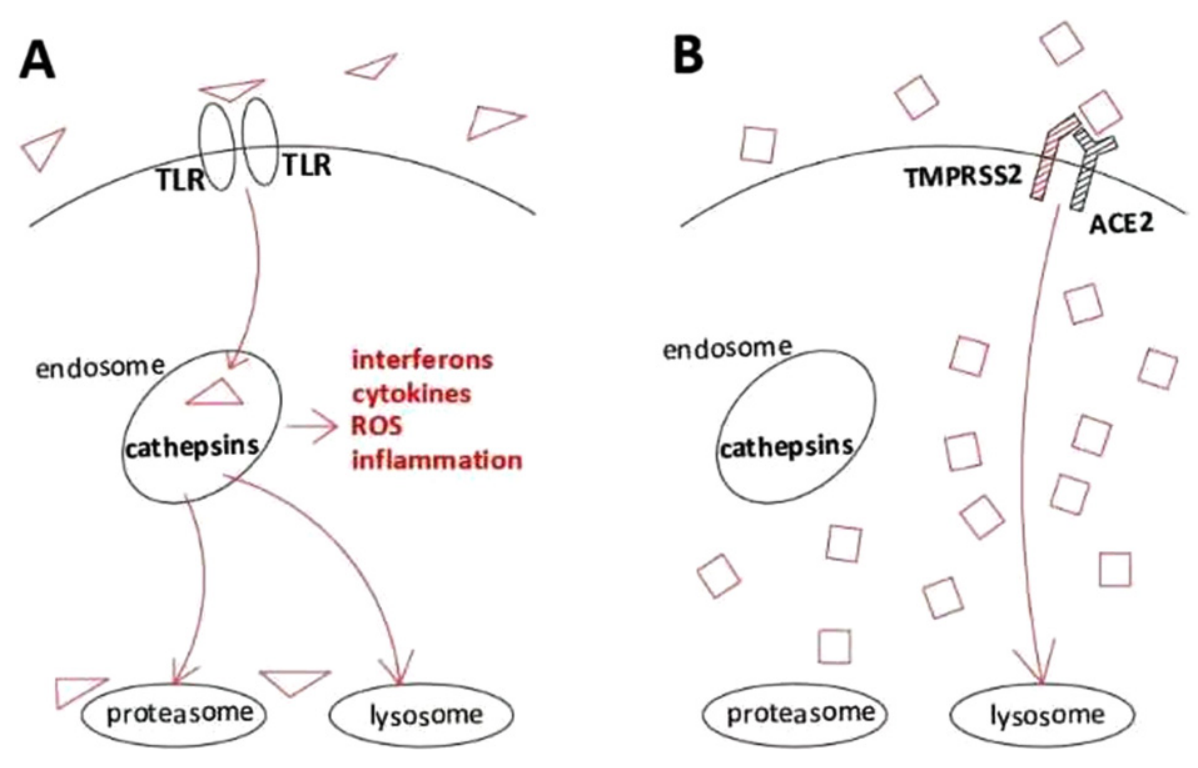

Fig. 2. Schematic depiction of internalisation pathways with dissimilar inflammatory effects triggered by different viruses. A, Activation of the TLR-mediated endosomal cathepsin pathway, initiating innate immune signaling, thus leading to higher cell inflammation and lower viral survival. ROS, reactive oxygen species (which damage DNA, thus predisposing to potentially carcinogenic genetic changes, including but not limited to TMPRSS2:ERG fusions). B, Activation of TMPRSS2/ACE2 intracellular trafficking, which bypasses endosomal capture and innate immunity, leading to lower cell inflammation and higher viral survival.

TLR-deficient mice are hypersusceptible to CVs [68], such viruses appear to have selected TMPRSS2 binding affinity in order to evade cathepsin-mediated inflammatory responses [69-72] (Fig. 2B). Viral subversion of inflammatory innate host cell defense via TMPRSS2-mediated endosomal TLR bypass thus provides a teleologic rationale: TMPRSS2 balances the strength of non-adaptive endocytotic pathogen defense against the severity of innate immune inflammatory reactions, such as could damage fertility in early adult life (see above) or predispose to multistep carcinogenesis during later life (see below). Of note, human papillomavirus (HPV)-positive head and neck cancers upregulate TMPRSS2 when compared with HPV-negative tumors [73], consistent with a defensive role in HPV infections, notwithstanding that E6/E7 expression may be driven by viral integration rather than replication.

\section{TMPRSS2 as an inflammation moderator}

The function of TMPRSS2 has sometimes been assumed to be that of a monofunctional protease, with a spectrum of substrates having been proposed: these include matriptase [22], PAR-2 [74], precursors of uroplasminogen activator and PSA [12], and of the c-Met ligand (pro-hepatocyte growth factor, HGF) [25]. No key physiologic proteolytic function of TMPRSS2 has yet been experimentally established, however - not even in the prostate, where the androgen-inducibility of TMPRSS 2 coupled to the secretion of its SP domain strongly implies a role in seminal fluid.

Recognition functions of the transmembrane zymogen could also contribute to a host defense mission of TMPRSS2. In the prostate, for example, androgenic induction of wild-type TMPRSS2 would enable certain phagocytosed antigens to bypass endosomal cathepsin L, thereby reducing the intensity of inflammatory damage, and maintaining tissue androgen-dependence by permitting survival of oxidantstressed epithelial cells which could otherwise (e.g., in the presence of TMPRSS2 gene loss) transform into prostate inflammatory atrophy (PIA) [75], prostatic intraepithelial neoplasia (PIN) or cancer [76]. 
Moreover, polynucleotide activation of prostatic endosomal TLR3 receptors causes innate NF $\kappa$ Bmediated inflammatory responses that trigger apoptosis of androgen-dependent cells, as may lead to androgen-independence [77, 78].

This is consistent with the established role of innate immunity in inflammatory $[79,80]$ and neoplastic processes $[81,82]$ in the prostate and other organs. In the prostate, for example, non-adaptive endocytotic reactions to non-self antigens can cause apoptotic loss of androgen-dependent cells in normal young adult males, suppressing progression to neoplastic invasion while maintaining androgen responsiveness of the remaining cell population [83-85]. With aging, however, prostatic senescence may give rise to an androgen- and cytokine-mediated senescence-associated secretory phenotype (SASP, inflammaging') that comes to exceed the anti-inflammatory capacity of TMPRSS2, and could thus play a role in benign prostatic hypertrophy (BPH) [86] or PIA [87]. Short-term SASP-driven inflammaging may inhibit neoplastic progression of immortalized (but not metastatic) cells [88], suggesting a protective effect of senescent inflammation against early cancer. However, more chronic androgen-dependent SASP selects for loss-of-function mutations affecting the tumor suppressor gene PTEN [89], driving tumor progression towards androgen-independence [90].

Ubiquitous skin microbiota such as Propionibacterium acnes (formerly Corynebacterium parvum, now reclassified as Cutibacterium acnes) have been implicated in chronic prostatic infections, BPH [91] and prostate cancer [92], possibly via stimulation of innate immunity-mediated inflammatory responses [93]. Phagosomic elimination of this bacterium itself appears independent of cathepsinmediated lysosomal fusion [94], however, raising the possibility of prostatic vulnerability to this infection due to androgen-inducible TMPRSS2 expression. Other sources of chronic intraprostatic inflammation include dietary carcinogens and estrogens [75], sexually transmissible bacterial infections such as Chlamydia and Neisseria spp., and viral infections such as herpes simplex-2 and HPV [95]. Hence, if TMPRSS2 does indeed have the function of moderating inflammation, the prostate appears to be an ideal tissue expression site.

\section{TMPRSS2 as a prostate protector}

The prostate ('protector' - Greek $\pi \rho 0 \sigma \tau \alpha \dot{\tau} \tau \varsigma)$ gland optimises male reproductive function by expediting outgoing sperm delivery, as well as by shielding from infection the seminal vesicles and epididymis; the latter organs are 100,000-fold less prone to cancer than the prostate, despite similar vulnerability to infection [96], reliance on innate immune responses [97], and DNA damage handling [95]. The hallmark androgen-inducibility of TMPRSS2 implies that a symbiotic balance between host defense optimisation and inflammation moderation could be most needed in the prostate, where androgen-driven sexual activity predisposes to microbial, xenobiotic or other pro-inflammatory exposures. The importance of this balance is suggested by an association of defective interferon-dependent functioning with prostate cancer risk in male cohorts with high numbers of lifetime sexual partners [98]. The gene of interest in this respect, IFNL4, plays a counterintuitive pro-viral anti-inflammatory role [99], reminiscent in this respect of TMPRSS2.

The pathogenetic importance of the endosomal pathway in the prostate is further supported by the finding that NADPH oxidase (NOX) proteins generating oxidant DNA damage are overexpressed in the endosomal compartments of prostate cancers [100]. Conversely, downregulation of tumor-promoting androgenic signaling occurs via endosomal/lysosomal degradation of androgen receptors induced by the suppressor gene TSG101 [101]. Hence, for prostate cancers which have progressed beyond early hormone-dependent growth, endosome-based innate immunity-mediated inflammatory positive feedback loops now represent a rational new therapeutic target [102]. 
Remarkably, the TMPRSS2:ERG fusion occurs in around 50\% of primary prostate cancers, making it one of the most consistent genetic aberrations in oncology, and in turn raising questions as to why this chromosomal fusion is so avidly selected. The androgen response element (ARE) in the TMPRSS2 5'-untranslated region is typically fused to the ETS-encoding ERG gene - conferring androgen-inducibility on the latter, and explaining both the association of TMPRSS2:ERG with hormone-dependent rather than castrate-resistant cancers [103], and the lack of potent transforming activity of the fusion gene [104].

These fusions often arise from $\sim 2.8 \mathrm{mB}$ deletions extending from the $21 \mathrm{q} 22.2$ ERG proto-oncogene to the telomeric TMPRSS2 gene; as such, the deleted region usually extends from the first intron of TMPRSS2 to the functional 3' ERG exons [21], excluding the TMPRSS2 coding region containing and beyond exon 2 [105]. These fusogenic deletions also tend to involve sixteen interstitial genes - some of which have tumor-suppressor activity, loss of which leads to progression that is independent of $E R G$ [106] - with such deletions being commoner than fusogenic translocations in castrate-resistant metastases [107].

Since TMPRSS2 protein translation is silenced in promoterless TMPRSS2-fused cells [1, 108] and given that the fused/deleted protein lacks protease activity [109], the tumor-specific selection of TMPRSS2 dysfunction is consistent with the hypothesis that this loss promotes tumor growth. The fact that some TMPRSS2:ERG fusion transcripts encode ERG proteins which are $N$-truncated due to premature stop codons [110] further implies that the selectability of these fusions could arise from TMPRSS2 loss of function per se rather than solely from ERG gain of function. These conclusions are also compatible with the findings that non-TMPRSS2:ERG prostate cancers are associated with autocatalytic TMPRSS2 processing that leads either to secretion of inactive fragments, and/or cytoplasmic mislocalization of dysfunctional full-length proteins [10, 35, 37].

Inflammation-induced oxidant DNA damage causing loss of TMPRSS2 protective function at the cellular level [36] predisposes at the chromosomal level to TMPRSS2:ERG fusion events [111]. Androgen-inducible ERG expression drives prostaglandin-mediated inflammation both in TMPRSS2:ERG-expressing prostate cancer cells [112] and tumors [113], a phenotype that is reinforced by ERG-inducible downregulation or loss of heterologous tumor suppressor genes such as $N K X 3.1$ [114]. This androgenic addiction cycle seems only breakable by evolution to androgen-independence [115]. Furthermore, anti-inflammatory cytokines repress both androgen receptor (AR) and TMPRSS2 expression in prostate cancer cells [116], and TMPRSS2:ERG-expressing incident prostate cancers occur less often in patient cohorts receiving anti-inflammatory drugs [117]. These findings imply that downregulation of TMPRSS2 in prostatic tissues, including but not limited to those containing TMPRSS2:ERG fusions, promotes androgen-driven prostate cancer by removing a negative constraint on endosomally-mediated inflammation, thereby synergizing with $E R G$-driven inflammation [113, $118]$.

Long-term non-senescent (e.g., microbial) inflammation may not only select for TMPRSS2:ERG fusions [111], but may also exacerbate prostatitis and promote evolution of androgen-dependent invasive cancer [119] or progression via epithelial-mesenchymal transition [120]. Such tumorigenicity can occur irrespective of ERG upregulation - which downregulates PTEN expression [121] - via direct selection for TMPRSS2 dysfunction [122, 123]. This predicts that if drug inhibitors are used to block prostatic TMPRSS2 with the aim of cancer prevention, inadvertently increasing inflammation, reduced selection for TMPRSS2-deleted fusion genes could result - i.e., despite the fact that in the absence of TMPRSS2 drug inhibition, inflammation selects for TMPRSS2:ERG fusions [111] - since in this drug-treated context there is no additional tumor-selecting advantage for a translocation that abrogates TMPRSS2 function. This reasoning predicts that TMPRSS2 protease-inhibitory drugs could reduce short-term low-grade androgen-dependent neoplasia but at the same time predispose to high-grade androgen-independent tumors. 
Carcinogenic inflammation in the prostate has been linked to high-fat diets [124, 125]. Dietary estrogens have been implicated as a specific cause of tumorigenic prostatitis [75], and estradiolactivated estrogen receptors $(\mathrm{ER} \alpha)$ induce TMPRSS 2 expression in extra-prostatic androgen-insensitive tissues such as the heart [126]. In prostate cancers the tumor-promoting function of TMPRSS2:ERG fusions appears mediated by ER $\alpha$ expression in basal epithelial cells, but may be repressed during early hormone-dependent disease by ER $\beta$ splice variants [127]. Since antiandrogen treatment of prostate cancer cells reduces TMPRSS 2 expression but also transactivates ER $\alpha$ expression via ESR 1 induction [128], a synergistic tumor-promoting effect of ER $\alpha$ expression and TMPRSS2 functional loss is a possibility. During progression to castrate-resistant prostate cancer (CRPC), non-canonical estradiol signaling via ER $\beta$ may supervene, triggering TMPRSS2:ETV 5 fusions in AR-null cells which - unlike TMPRSS2:ERG fusions in AR-expressing cells - drive NF- $\kappa \mathrm{B}$-dependent metastasis in the absence of innate immune signaling upregulation [129].

\section{TMPRSS2 as a tumor suppressor}

The heterogeneity of TMPRSS 2 and ERG-like aberrations in prostate cancers [2] creates challenges for etiopathogenetic assessment [130]. Cancer-associated fusion genes may arise via intra- or interchromosomal rearrangements, with such clonal rearrangements implying tumor selection for a driver genotype [24]; in most instances the 5' gene sequence drives expression of the 3 ' gene partner, with 'actionable' inhibitors of the latter gene product - or downstream targets thereof [131] - often able to slow tumor growth [132]. Since the TMPRSS2:ERG genotype is an upregulating ARE-ERG fusion accompanied by loss of normal TMPRSS 2 function, with the latter gene contributing only untranslated sequences to the fusion [104], data showing TMPRSS2 gene induction in such tumors $[12,18,133]$ should not be interpreted as signifying overactivity of the normal functional protein. Moreover, in one study reporting prostate cancer-specific TMPRSS2 overexpression based on in situ hybridization, the only TMPRSS2 gene aberration was a protease-inactivating null mutation [134]. This and other groups also reported that prostate cancer cell progression to androgen-independence is associated with TMPRSS2 downregulation [135].

Upregulation of a given wild-type transcript or protein in tumor tissue, unassociated with selectable hardwired genotypes such as gene amplification, is hard to interpret, since it could imply either a primary oncogenic driver or secondary (i.e., reactive, compensatory or suppressor) regulatory role. Relevant to this, one study showed that TMPRSS2 expression is upregulated in a subset of tumors including not only prostate cancer and HPV-positive cervix cancer, but also cancers of the rectum, colon and stomach; this transcriptional upregulation was associated with promoter hypomethylation, but not with increased TMPRSS2 copy number [136]. A further study likewise showed ACE2 transcriptional upregulation due to promoter hypomethylation in rectal, colon and stomach tumors, as well as similar methylationinduced downregulation in testicular and thyroid cancers [137]. Considered in the context of their collaborative endosome-bypassing anti-inflammatory roles, these studies suggest that the previously reported tumor-suppressive properties of ACE2 [138] may be supplemented in tandem by its membrane partner TMPRSS2.

The ERG fusion event involving TMPRSS2 loss of function is implicated in early, but not late, prostatic neoplasms [108]; moreover, judged by immunohistochemical expression, there is no difference in TMPRSS2 protein expression between malignant and benign tumors [37], nor between poorlyand well-differentiated neoplasms $[22,35]$. Although these findings do not suggest a proto-oncogenic function for TMPRSS2, support for a pro-metastatic action has been forthcoming from studies using transformed model systems such as xenografts [22] or SV40-driven tumor-bearing TRAMP mice [25]. In the latter study the protease inhibitor bromhexine blocked TMPRSS2 activity while also 
reducing prostate cancer metastasis in vivo; more recent research reported that bromhexine does not inhibit TMPRSS2, however, and also noted that the TRAMP mouse study used a TMPRSS2 recombinant lacking the LDLRA domain [20]. Another intriguing finding of the TRAMP study was that Tmprss2-1- mice with deletions of TMPRSS2 produced tumors over double the size of those occurring in Tmprss $2+/+$ mice [25], suggesting a tumor-suppressor function. The lack of TMPRSS 2 gene amplification events reported in prostate tumors, as well as the reported homozygous loss of TMPRSS2 in cancer cell lines [139], further favor a suppressor role. Additional support for this interpretation comes from the original subtractive cloning of TMPRSS2 as a gene downregulated in bone metastases [26], as well as from frameshift loss-of-function TMPRSS2 mutations occurring in metastatic prostate tumors [140].

These findings do not exclude the possibility that TMPRSS2 plays different roles in different contexts, e.g., in the normal prostate, in the development of hormone-dependent invasive cancer, and/or in progression to castrate-resistant metastatic disease. Since cancer evolution may be associated with a gene changing its function due to epistatic effects [141] - with such genes comparable to electronic components, the effect of which depends upon placement in a circuit [142] - it is possible that in the metastatic context TMPRSS2, either independently or via interaction with other TTSPs [109], could drive tumor dissemination by a path involving, say, proteolytic activation of pro-HGF in extracellular matrix $[22,25]$. One study supporting this hypothesis showed that a recombinant TMPRSS2 inhibitor reduced prostate cancer cell invasion and metastasis [143]; however, the same inhibitor had earlier been reported to inhibit invasion and metastasis of lung cancer cells [144] for which TMPRSS2 is not a co-factor.

A key concern relating to the notion of TMPRSS2 as a tumor suppressor in the prostate is that selection for the TMPRSS2:ERG fusion removes only one functional TMPRSS2 copy. Hence, given that even homozygous knockouts have shown no discernible phenotype $[40,45]$, it is fair to ask whether or not such a heterozygous loss could plausibly manifest as haploinsufficiency and thus contribute to pro-inflammatory cancer progression 'beyond ERG', as it were [145]. We previously reported that homozygous knockouts of caretaker tumor suppressor genes - which maintain cell and genomic integrity, unlike gatekeeper suppressor genes which regulate apoptotic threshold and cellcycle traverse - generally yield viable offspring of normal phenotype but impaired male fertility [146]. As noted earlier, male infertility as a haploinsufficient phenotype of TMPRSS2 loss could well be conditional on thresholds for sterility-inducing testicular inflammation, such as may vary with epidemic viral orchitis or ACE2 hypofunction. The high frequency of TMPRSS2:ERG fusion events in prostate cancer mirrors this conditionality by creating the precise circumstances needed to unmask the modest $50 \%$ decline in TMPRSS2 function predicted by protein alone; for this 20-100-fold androgendriven $E R G$ fusion/upregulation event [147] induces exactly the prostaglandin- [112, 148] and innate immunity-mediated inflammatory insults $[79,102]$ that wild-type TMPRSS2 ameliorates both in lung infections [149] and in the prostate [80, 116]. Hence, in this context the TMPRSS2:ERG gene fusion represents the perfect gene imbalance to reveal TMPRSS2 haploinsufficiency [46]. Similarly, an ideal environment to promote selection for TMPRSS2 dysfunction (i.e., such as could in due course undergo fixation as a TMPRSS2:ERG fusion) would be prostatitis of a subtype that is usually controllable by TMPRSS2 transcriptional upregulation alone, but which in severe or prolonged cases stochastically or stoichiometrically overwhelms normal capacity (Table 2 ).

A limitation of this model is that there is as yet no definitive evidence whether the putative TMPRSS2 molecular targets in the normal prostate - involving either proteolytic or non-proteolytic interactions - are microbial antigens [120,150], inflammation-associated molecules [151], or tumor neoantigens [152]. Further work is needed for elucidation, including controlled comparisons of null vs. SP-only TMPRSS2 knockout mice under stressed conditions, such as microbial infections, short- and long-term inflammation, and/or high testosterone levels. 
Table 2

Genetic or environmental variables that could unmask TMPRSS2 haploinsufficiency ${ }^{2}$

\begin{tabular}{lcc}
\hline Genotype: TMPRSS2 loss & \multicolumn{2}{c}{ Conditional haploinsufficiency } \\
\cline { 2 - 3 } & Genetic & Environmental \\
\hline Phenotype: & ACE2 loss & Viral orchitis \\
Male infertility & ARE:ERG fusion & Chronic prostatitis \\
Inflammatory prostate carcinogenesis &
\end{tabular}

${ }^{2}$ Based on references in the text, hypothesised polygenic or extrinsic triggers that could convert TMPRSS2 from apparent redundancy or heterozygous haplosufficiency to conditional haploinsufficiency, with respect either to male infertility or prostate cancer development. ARE, functional 5' androgen response element of exon-deleted TMPRSS2.

\section{Conclusions}

The recently recognised role of TMPRSS2 in SARS-COV-2 infection has spawned hypotheses that antiandrogens and/or TMPRSS2 inhibitors could reduce viral infectivity. The credibility of these hypotheses has since been supported by studies which indicate that SARS-COV-2 and other RNA viruses have evolved their predilection for TMPRSS2-mediated cell entry as a way of evading the host's innate immune inflammatory reactions, thus enhancing viral infectivity. Clinical trials will soon assess the utility of targeted drug antagonists in this disease setting.

The notably high frequency of fusions between the TMPRSS2 and ERG genes in early hormonedependent prostate cancers has likewise suggested that one or both of these gene products could be useful anticancer drug targets. However, data confirming a targetable driver role for TMPRSS2 in the setting of primary prostate cancer - this being the clinical context in which TMPRSS2:ERG gene fusions are most relevant - remain weak. In contrast, there is growing albeit still circumstantial evidence as to a role for wild-type TMPRSS2 in moderating the infertility and/or neoplastic consequences of uncontrolled inflammation in the testis and/or prostate. Since worsening of inflammatory damage could be counterproductive, caution remains appropriate for applying TMPRSS2 inhibition to the preventive or early cancer treatment settings.

\section{Acknowledgments}

Kind support from the family of Mr Frank Wolf /Curran Foundation is gratefully acknowledged.

\section{Conflict of interest}

The author has no conflicts of interest to report.

\section{References}

[1] Thunders M, Delahunt B. Gene of the month: Tmprss2 (transmembrane serine protease 2). J Clin Pathol. 2020;73: 773-6. 
[2] Perner S, Demichelis F, Beroukhim R, Schmidt FH, Mosquera JM, Setlur S, Tchinda J, Tomlins SA, Hofer MD, Pienta KG, Kuefer R, Vessella R, Sun XW, Meyerson M, Lee C, Sellers WR, Chinnaiyan AM, Rubin MA. Tmprss2:Erg fusion-associated deletions provide insight into the heterogeneity of prostate cancer. Cancer Res. 2006;66:8337-41.

[3] Mjaess G, Karam A, Aoun F, Albisinni S, Roumeguere T. Covid-19 and the male susceptibility: The role of ace2, tmprss 2 and the androgen receptor. Prog Urol. 2020;30:484-7.

[4] Mattsson JM, Ravela S, Hekim C, Jonsson M, Malm J, Narvanen A, Stenman UH, Koistinen H. Proteolytic activity of prostate-specific antigen (psa) towards protein substrates and effect of peptides stimulating psa activity. PLoS One. 2014;9:e107819.

[5] McKee CM, Xu D, Kessler BM, Muschel RJ. Proteomic analysis reveals a proteolytic feedback loop in murine seminal fluid. Prostate. 2013;73:1427-40.

[6] Filippou PS, Karagiannis GS, Musrap N, Diamandis EP. Kallikrein-related peptidases (klks) and the hallmarks of cancer. Crit Rev Clin Lab Sci. 2016;53:277-291.

[7] Jha SK, Rauniyar K, Chronowska E, Mattonet K, Maina EW, Koistinen H, Stenman UH, Alitalo K, Jeltsch M. Klk3/psa and cathepsin d activate vegf-c and vegf-d. Elife. 2019;8:e44478.

[8] Fuhrman-Luck RA, Loessner D, Clements JA. Kallikrein-related peptidases in prostate cancer: From molecular function to clinical application. EJIFCC. 2014;25:269-81.

[9] Bonk S, Kluth M, Jansen K, Hube-Magg C, Makrypidi-Fraune G, Hoflmayer D, Weidemann S, Moller K, Uhlig R, Buscheck F, Luebke AM, Burandt E, Clauditz TS, Steurer S, Schlomm T, Huland H, Heinzer H, Sauter G, Simon R, Dum D. Reduced klk2 expression is a strong and independent predictor of poor prognosis in erg-negative prostate cancer. Prostate. 2020;80:1097-107.

[10] Afar DE, Vivanco I, Hubert RS, Kuo J, Chen E, Saffran DC, Raitano AB, Jakobovits A. Catalytic cleavage of the androgen-regulated tmprss 2 protease results in its secretion by prostate and prostate cancer epithelia. Cancer Res. 2001;61:1686-92.

[11] Vaarala MH, Porvari KS, Kellokumpu S, Kyllonen AP, Vihko PT. Expression of transmembrane serine protease tmprss2 in mouse and human tissues. J Pathol. 2001;193:134-40.

[12] Lin B, Ferguson C, White JT, Wang S, Vessella R, True LD, Hood L, Nelson PS. Prostate-localized and androgenregulated expression of the membrane-bound serine protease tmprss2. Cancer Res 1999;59:4180-4.

[13] Lukassen S, Chua RL, Trefzer T, Kahn NC, Schneider MA, Muley T, Winter H, Meister M, Veith C, Boots AW, Hennig BP, Kreuter M, Conrad C, Eils R. Sars-cov-2 receptor ace2 and tmprss2 are primarily expressed in bronchial transient secretory cells. EMBO J. 2020:e105114.

[14] Klein EA, Li J, Milinovich A, Schold JD, Sharifi N, Kattan MW, Jehi L. Androgen deprivation therapy in men with prostate cancer does not affect risk of infection with sars-cov-2. J Urol. 2020:101097JU0000000000001338.

[15] Montopoli M, Zumerle S, Vettor R, Rugge M, Zorzi M, Catapano CV, Carbone GM, Cavalli A, Pagano F, Ragazzi E, Prayer-Galetti T, Alimonti A. Androgen-deprivation therapies for prostate cancer and risk of infection by sars-cov-2: A population-based study ( $n=4532)$. Ann Oncol. 2020;31:1040-45.

[16] Bahmad HF, Abou-Kheir W. Crosstalk between covid-19 and prostate cancer. Prostate Cancer Prostatic Dis. 2020;23:561-63.

[17] McCoy J, Wambier CG, Vano-Galvan S, Shapiro J, Sinclair R, Ramos PM, Washenik K, Andrade M, Herrera S, Goren A. Racial variations in covid-19 deaths may be due to androgen receptor genetic variants associated with prostate cancer and androgenetic alopecia. Are anti-androgens a potential treatment for covid-19? J Cosmet Dermatol. 2020;19:1542-3.

[18] Mollica V, Rizzo A, Massari F. The pivotal role of tmprss2 in coronavirus disease 2019 and prostate cancer. Future Oncol. 2020;16:2029-33.

[19] Bhowmick NA, Oft J, Dorff T, Pal S, Agarwal N, Figlin RA, Posadas EM, Freedland S, Gong J. Covid-19 and androgen targeted therapy for prostate cancer patients. Endocr Relat Cancer. 2020;27:R281-92.

[20] Shrimp JH, Kales SC, Sanderson PE, Simeonov A, Shen M, Hall MD. An enzymatic tmprss2 assay for assessment of clinical candidates and discovery of inhibitors as potential treatment of covid-19. ACS Pharmacol Transl Sci. 2020;3:997-1007.

[21] Tomlins SA, Rhodes DR, Perner S, Dhanasekaran SM, Mehra R, Sun XW, Varambally S, Cao X, Tchinda J, Kuefer R, Lee C, Montie JE, Shah RB, Pienta KJ, Rubin MA, Chinnaiyan AM. Recurrent fusion of tmprss 2 and ets transcription factor genes in prostate cancer. Science. 2005;310:644-8.

[22] Ko CJ, Huang CC, Lin HY, Juan CP, Lan SW, Shyu HY, Wu SR, Hsiao PW, Huang HP, Shun CT, Lee MS. Androgeninduced tmprss 2 activates matriptase and promotes extracellular matrix degradation, prostate cancer cell invasion, tumor growth, and metastasis. Cancer Res. 2015;75:2949-60. 
[23] Stopsack KH, Mucci LA, Antonarakis ES, Nelson PS, Kantoff PW. Tmprss2 and covid-19: Serendipity or opportunity for intervention? Cancer Discov. 2020;10.779-82.

[24] Gao Q, Liang WW, Foltz SM, Mutharasu G, Jayasinghe RG, Cao S, Liao WW, Reynolds SM, Wyczalkowski MA, Yao L, Yu L, Sun SQ, Fusion Analysis Working G, Cancer Genome Atlas Research N, Chen K, Lazar AJ, Fields RC, Wendl MC, Van Tine BA, Vij R, Chen F, Nykter M, Shmulevich I, Ding L. Driver fusions and their implications in the development and treatment of human cancers. Cell Rep. 2018;23:227-238 e223.

[25] Lucas JM, Heinlein C, Kim T, Hernandez SA, Malik MS, True LD, Morrissey C, Corey E, Montgomery B, Mostaghel E, Clegg N, Coleman I, Brown CM, Schneider EL, Craik C, Simon JA, Bedalov A, Nelson PS. The androgen-regulated protease tmprss 2 activates a proteolytic cascade involving components of the tumor microenvironment and promotes prostate cancer metastasis. Cancer Discov. 2014;4:1310-25.

[26] Paoloni-Giacobino A, Chen H, Peitsch MC, Rossier C, Antonarakis SE. Cloning of the tmprss2 gene, which encodes a novel serine protease with transmembrane, ldlra, and srcr domains and maps to 21q22.3. Genomics. 1997;44: $309-20$.

[27] Hoffmann M, Kleine-Weber H, Schroeder S, Kruger N, Herrler T, Erichsen S, Schiergens TS, Herrler G, Wu NH, Nitsche A, Muller MA, Drosten C, Pohlmann S. Sars-cov-2 cell entry depends on ace2 and tmprss2 and is blocked by a clinically proven protease inhibitor. Cell. 2020;181:271-80.

[28] Kim SY, Park D, Oh M, Sellamuthu S, Park WJ. Detection of site-specific proteolysis in secretory pathways. Biochem Biophys Res Commun. 2002;296:419-24.

[29] Lee CF, Dang A, Hernandez E, Pong RC, Chen B, Sonavane R, Raj G, Kapur P, Lin HY, Wu SR, Ko CJ, Lo UG, Lee HY, Hsieh JT, Lee MS. Activation of sphingosine kinase by lipopolysaccharide promotes prostate cancer cell invasion and metastasis via sphk1/s1pr4/matriptase. Oncogene. 2019;38:5580-98.

[30] Martinez VG, Moestrup SK, Holmskov U, Mollenhauer J, Lozano F. The conserved scavenger receptor cysteine-rich superfamily in therapy and diagnosis. Pharmacol Rev. 2011;63:967-1000.

[31] Townes CL, Ali A, Gross N, Pal D, Williamson S, Heer R, Robson CN, Pickard RS, Hall J. Prostate specific antigen enhances the innate defence of prostatic epithelium against escherichia coli infection. Prostate. 2013;73: 1529-37.

[32] Langston ME, Pakpahan R, Nevin RL, De Marzo AM, Elliott DJ, Gaydos CA, Isaacs WB, Nelson WG, Sokoll LJ, Zenilman JM, Platz EA, Sutcliffe S. Sustained influence of infections on prostate-specific antigen concentration: An analysis of changes over 10 years of follow-up. Prostate. 2018;78:1024-34.

[33] Milbrandt M, Winter AC, Nevin RL, Pakpahan R, Bradwin G, De Marzo AM, Elliott DJ, Gaydos CA, Isaacs WB, Nelson WG, Rifai N, Sokoll LJ, Zenilman JM, Platz EA, Sutcliffe S. Insight into infection-mediated prostate damage: Contrasting patterns of c-reactive protein and prostate-specific antigen levels during infection. Prostate. 2017;77: 1325-34.

[34] Demir S. Role of sterile pyuria in association to elevated psa values in the diagnosis of non-palpable prostate cancer? Arch Ital Urol Androl. 2019;91:doi.10.4081/aiua.2019.3.167

[35] Chen YW, Lee MS, Lucht A, Chou FP, Huang W, Havighurst TC, Kim K, Wang JK, Antalis TM, Johnson MD, Lin CY. Tmprss2, a serine protease expressed in the prostate on the apical surface of luminal epithelial cells and released into semen in prostasomes, is misregulated in prostate cancer cells. Am J Pathol. 2010;176:2986-96.

[36] Paszti-Gere E, Barna RF, Kovago C, Szauder I, Ujhelyi G, Jakab C, Meggyeshazi N, Szekacs A. Changes in the distribution of type ii transmembrane serine protease, tmprss 2 and in paracellular permeability in ipec- 2 cells exposed to oxidative stress. Inflammation. 2015;38:775-83.

[37] Lucas JM, True L, Hawley S, Matsumura M, Morrissey C, Vessella R, Nelson PS. The androgen-regulated type ii serine protease tmprss2 is differentially expressed and mislocalized in prostate adenocarcinoma. J Pathol. 2008;215: $118-25$.

[38] Guipponi M, Antonarakis SE, Scott HS. Tmprss3, a type ii transmembrane serine protease mutated in non-syndromic autosomal recessive deafness. Front Biosci. 2008;13:1557-67.

[39] Donaldson SH, Hirsh A, Li DC, Holloway G, Chao J, Boucher RC, Gabriel SE. Regulation of the epithelial sodium channel by serine proteases in human airways. J Biol Chem. 2002;277:8338-45.

[40] Kim TS, Heinlein C, Hackman RC, Nelson PS. Phenotypic analysis of mice lacking the tmprss2-encoded protease. Mol Cell Biol. 2006;26:965-75.

[41] List K, Haudenschild CC, Szabo R, Chen W, Wahl SM, Swaim W, Engelholm LH, Behrendt N, Bugge TH. Matriptase/mt-sp1 is required for postnatal survival, epidermal barrier function, hair follicle development, and thymic homeostasis. Oncogene. 2002;21:3765-79.

[42] Shukla KK, Mahdi AA, Rajender S. Ion channels in sperm physiology and male fertility and infertility. $J$ Androl. 2012;33:777-88 
[43] Toure A, Lhuillier P, Gossen JA, Kuil CW, Lhote D, Jegou B, Escalier D, Gacon G. The testis anion transporter 1 (slc26a8) is required for sperm terminal differentiation and male fertility in the mouse. Hum Mol Genet. 2007;16: 1783-93.

[44] Peters TA, Levtchenko E, Cremers CW, Curfs JH, Monnens LA. No evidence of hearing loss in pseudohypoaldosteronism type 1 patients. Acta Otolaryngol. 2006;126:237-9.

[45] Whitworth KM, Benne JA, Spate LD, Murphy SL, Samuel MS, Murphy CN, Richt JA, Walters E, Prather RS, Wells KD. Zygote injection of crispr/cas9 rna successfully modifies the target gene without delaying blastocyst development or altering the sex ratio in pigs. Transgenic Res. 2017;26:97-107.

[46] Johnson AF, Nguyen HT, Veitia RA. Causes and effects of haploinsufficiency. Biol Rev Camb Philos Soc. 2019;94: 1774-85.

[47] Wu H, Wang F, Tang D, Han D. Mumps orchitis: Clinical aspects and mechanisms. Front Immunol. 2021;12:582946.

[48] Franz S, Rennert P, Woznik M, Grutzke J, Ludde A, Arriero Pais EM, Finsterbusch T, Geyer H, Mankertz A, Friedrich N. Mumps virus sh protein inhibits nf-kappab activation by interacting with tumor necrosis factor receptor 1, interleukin-1 receptor 1, and toll-like receptor 3 complexes. J Virol. 2017;91:e01037-17.

[49] Simmons G, Zmora P, Gierer S, Heurich A, Pohlmann S. Proteolytic activation of the sars-coronavirus spike protein: Cutting enzymes at the cutting edge of antiviral research. Antiviral Res. 2013;100:605-14.

[50] Ren X, Wang S, Chen X, Wei X, Li G, Ren S, Zhang T, Zhang X, Lu Z, You Z, Wang Z, Song N, Qin C. Multiple expression assessments of ace 2 and tmprss 2 sars-cov- 2 entry molecules in the urinary tract and their associations with clinical manifestations of covid-19. Infect Drug Resist. 2020;13:3977-90.

[51] Navarra A, Albani E, Castellano S, Arruzzolo L, Levi-Setti PE. Coronavirus disease-19 infection: Implications on male fertility and reproduction. Front Physiol. 2020;11:574761.

[52] Pan F, Xiao X, Guo J, Song Y, Li H, Patel DP, Spivak AM, Alukal JP, Zhang X, Xiong C, Li PS, Hotaling JM. No evidence of severe acute respiratory syndrome-coronavirus 2 in semen of males recovering from coronavirus disease 2019. Fertil Steril. 2020;113:1135-39.

[53] Song J, Li Y, Huang X, Chen Z, Li Y, Liu C, Chen Z, Duan X. Systematic analysis of ace2 and tmprss2 expression in salivary glands reveals underlying transmission mechanism caused by sars-cov-2. J Med Virol. 2020;92: 2556-66.

[54] Meng Y, Yu CH, Li W, Li T, Luo W, Huang S, Wu PS, Cai SX, Li X. Angiotensin-converting enzyme 2/angiotensin(1-7)/mas axis protects against lung fibrosis by inhibiting the mapk/nf-kappab pathway. Am J Respir Cell Mol Biol. 2014;50:723-736.

[55] Rodrigues Prestes TR, Rocha NP, Miranda AS, Teixeira AL, Simoes ESAC. The anti-inflammatory potential of ace2/angiotensin-(1-7)/mas receptor axis: Evidence from basic and clinical research. Curr Drug Targets. 2017;18: 1301-13.

[56] Shulla A, Heald-Sargent T, Subramanya G, Zhao J, Perlman S, Gallagher T. A transmembrane serine protease is linked to the severe acute respiratory syndrome coronavirus receptor and activates virus entry. J Virol. 2011;85: 873-882.

[57] Ratajczak MZ, Bujko K, Ciechanowicz A, Sielatycka K, Cymer M, Marlicz W, Kucia M. Sars-cov-2 entry receptor ace2 is expressed on very small cd45(-) precursors of hematopoietic and endothelial cells and in response to virus spike protein activates the nlrp3 inflammasome. Stem Cell Rev Rep. 2021;17:266-77.

[58] Kimura H, Francisco D, Conway M, Martinez FD, Vercelli D, Polverino F, Billheimer D, Kraft M. Type 2 inflammation modulates ace2 and tmprss2 in airway epithelial cells. J Allergy Clin Immunol. 2020;146:80-88 e88.

[59] Liu X, Chen Y, Tang W, Zhang L, Chen W, Yan Z, Yuan P, Yang M, Kong S, Yan L, Qiao J. Single-cell transcriptome analysis of the novel coronavirus (sars-cov-2) associated gene ace2 expression in normal and non-obstructive azoospermia (noa) human male testes. Sci China Life Sci. 2020;63:1006-15.

[60] Limburg H, Harbig A, Bestle D, Stein DA, Moulton HM, Jaeger J, Janga H, Hardes K, Koepke J, Schulte L, Koczulla AR, Schmeck B, Klenk HD, Bottcher-Friebertshauser E. Tmprss2 is the major activating protease of influenza a virus in primary human airway cells and influenza b virus in human type ii pneumocytes. $J$ Virol. 2019;93:e00649-19.

[61] Abe M, Tahara M, Sakai K, Yamaguchi H, Kanou K, Shirato K, Kawase M, Noda M, Kimura H, Matsuyama S, Fukuhara H, Mizuta K, Maenaka K, Ami Y, Esumi M, Kato A, Takeda M. Tmprss2 is an activating protease for respiratory parainfluenza viruses. $J$ Virol. 2013;87:11930-35.

[62] Esumi M, Ishibashi M, Yamaguchi H, Nakajima S, Tai Y, Kikuta S, Sugitani M, Takayama T, Tahara M, Takeda M, Wakita T. Transmembrane serine protease tmprss2 activates hepatitis c virus infection. Hepatology. 2015;61:437-46.

[63] Cheng Z, Zhou J, To KK, Chu H, Li C, Wang D, Yang D, Zheng S, Hao K, Bosse Y, Obeidat M, Brandsma CA, Song YQ, Chen Y, Zheng BJ, Li L, Yuen KY. Identification of tmprss2 as a susceptibility gene for severe 2009 pandemic $\mathrm{a}(\mathrm{h} 1 \mathrm{n} 1)$ influenza and a(h7n9) influenza. J Infect Dis. 2015;212:1214-21. 
[64] Matsuyama S, Nao N, Shirato K, Kawase M, Saito S, Takayama I, Nagata N, Sekizuka T, Katoh H, Kato F, Sakata M, Tahara M, Kutsuna S, Ohmagari N, Kuroda M, Suzuki T, Kageyama T, Takeda M. Enhanced isolation of sars-cov-2 by tmprss2-expressing cells. Proc Natl Acad Sci U S A. 2020;117:7001-3.

[65] Qing E, Hantak MP, Galpalli GG, Gallagher T. Evaluating mers-cov entry pathways. Methods Mol Biol. 2020;2099: 9-20.

[66] Zhou Y, Vedantham P, Lu K, Agudelo J, Carrion R, Jr., Nunneley JW, Barnard D, Pohlmann S, McKerrow JH, Renslo AR, Simmons G. Protease inhibitors targeting coronavirus and filovirus entry. Antiviral Res. 2015;116:76-84.

[67] Jensen S, Thomsen AR. Sensing of rna viruses: A review of innate immune receptors involved in recognizing rna virus invasion. J Virol. 2012;86:2900-10.

[68] Totura AL, Whitmore A, Agnihothram S, Schafer A, Katze MG, Heise MT, Baric RS. Toll-like receptor 3 signaling via trif contributes to a protective innate immune response to severe acute respiratory syndrome coronavirus infection. mBio. 2015;6:e0638-00615.

[69] Shirato K, Kanou K, Kawase M, Matsuyama S. Clinical isolates of human coronavirus 229e bypass the endosome for cell entry. J Virol. 2017;91:e01387-16.

[70] Kindler E, Thiel V. To sense or not to sense viral rna-essentials of coronavirus innate immune evasion. Curr Opin Microbiol. 2014;20:69-75.

[71] Wong LY, Lui PY, Jin DY. A molecular arms race between host innate antiviral response and emerging human coronaviruses. Virol Sin. 2016;31:12-23.

[72] Mettelman RC, O'Brien A, Whittaker GR, Baker SC. Generating and evaluating type i interferon receptor-deficient and feline tmprss2-expressing cells for propagating serotype i feline infectious peritonitis virus. Virology. 2019;537: 226-236.

[73] Sacconi A, Donzelli S, Pulito C, Ferrero S, Spinella F, Morrone A, Rigoni M, Pimpinelli F, Ensoli F, Sanguineti G, Pellini R, Agrawal N, Izumchenko E, Ciliberto G, Gianni A, Muti P, Strano S, Blandino G. Tmprss2, a sars-cov-2 internalization protease is downregulated in head and neck cancer patients. J Exp Clin Cancer Res. 2020;39:200.

[74] Wilson S, Greer B, Hooper J, Zijlstra A, Walker B, Quigley J, Hawthorne S. The membrane-anchored serine protease, tmprss2, activates par-2 in prostate cancer cells. Biochem J. 2005;388:967-972.

[75] Nelson WG, Demarzo AM, Yegnasubramanian S. The diet as a cause of human prostate cancer. Cancer Treat Res. 2014;159:51-68.

[76] Zhang S, Pavlovitz B, Tull J, Wang Y, Deng FM, Fuller C. Detection of tmprss2 gene deletions and translocations in carcinoma, intraepithelial neoplasia, and normal epithelium of the prostate by direct fluorescence in situ hybridization. Diagn Mol Pathol. 2010;19:151-156.

[77] Paone A, Starace D, Galli R, Padula F, De Cesaris P, Filippini A, Ziparo E, Riccioli A. Toll-like receptor 3 triggers apoptosis of human prostate cancer cells through a pkc-alpha-dependent mechanism. Carcinogenesis. 2008;29:13341342.

[78] Palchetti S, Starace D, De Cesaris P, Filippini A, Ziparo E, Riccioli A. Transfected poly(i:C) activates different dsrna receptors, leading to apoptosis or immunoadjuvant response in androgen-independent prostate cancer cells. $J$ Biol Chem. 2015;290:5470-5483.

[79] Wang J, Cai Y, Shao LJ, Siddiqui J, Palanisamy N, Li R, Ren C, Ayala G, Ittmann M. Activation of nf-kappab by tmprss2/erg fusion isoforms through toll-like receptor-4. Cancer Res. 2011;71:1325-33.

[80] Ou T, Lilly M, Jiang W. The pathologic role of toll-like receptor 4 in prostate cancer. Front Immunol. 2018;9: 1188.

[81] Kazma R, Mefford JA, Cheng I, Plummer SJ, Levin AM, Rybicki BA, Casey G, Witte JS. Association of the innate immunity and inflammation pathway with advanced prostate cancer risk. PLoS One. 2012;7:e51680.

[82] Magnifico MC, Macone A, Marani M, Bouzidi A, Giardina G, Rinaldo S, Cutruzzola F, Paone A. Linking infection and prostate cancer progression: Toll-like receptor3 stimulation rewires glucose metabolism in prostate cells. Anticancer Res. 2019;39:5541-9.

[83] Kuang AG, Nickel JC, Andriole GL, Castro-Santamaria R, Freedland SJ, Moreira DM. Both acute and chronic inflammation are associated with less perineural invasion in men with prostate cancer on repeat biopsy. BJU Int. 2019;123:91-97.

[84] Taverna G, Pedretti E, Di Caro G, Borroni EM, Marchesi F, Grizzi F. Inflammation and prostate cancer: Friends or foe? Inflamm Res. 2015;64:275-86.

[85] Vasavada SR, Dobbs RW, Kajdacsy-Balla AA, Abern MR, Moreira DM. Inflammation on prostate needle biopsy is associated with lower prostate cancer risk: A meta-analysis. J Urol. 2018;199:1174-81.

[86] Vital P, Castro P, Tsang S, Ittmann M. The senescence-associated secretory phenotype promotes benign prostatic hyperplasia. Am J Pathol. 2014;184:721-31. 
[87] Vral A, Magri V, Montanari E, Gazzano G, Gourvas V, Marras E, Perletti G. Topographic and quantitative relationship between prostate inflammation, proliferative inflammatory atrophy and low-grade prostate intraepithelial neoplasia: A biopsy study in chronic prostatitis patients. Int J Oncol. 2012;41:1950-8.

[88] Alessio N, Aprile D, Squillaro T, Di Bernardo G, Finicelli M, Melone MA, Peluso G, Galderisi U. The senescenceassociated secretory phenotype (sasp) from mesenchymal stromal cells impairs growth of immortalized prostate cells but has no effect on metastatic prostatic cancer cells. Aging (Albany NY). 2019;11:5817-28.

[89] Laberge RM, Sun Y, Orjalo AV, Patil CK, Freund A, Zhou L, Curran SC, Davalos AR, Wilson-Edell KA, Liu S, Limbad C, Demaria M, Li P, Hubbard GB, Ikeno Y, Javors M, Desprez PY, Benz CC, Kapahi P, Nelson PS, Campisi J. Mtor regulates the pro-tumorigenic senescence-associated secretory phenotype by promoting illa translation. Nat Cell Biol. 2015;17:1049-61.

[90] Han B, Mehra R, Lonigro RJ, Wang L, Suleman K, Menon A, Palanisamy N, Tomlins SA, Chinnaiyan AM, Shah RB. Fluorescence situ hybridization study shows association of pten deletion with erg rearrangement during prostate cancer progression. Mod Pathol. 2009;22:1083-93.

[91] Radej S, Plaza P, Olender A, Szewc M, Bar K, Maciejewski R. Infiltrating treg and th17 cells of the prostate hypertrophy gland associated with propionibacterium acnes infection. Res Rep Urol. 2020;12:593-97.

[92] Davidsson S, Molling P, Rider JR, Unemo M, Karlsson MG, Carlsson J, Andersson SO, Elgh F, Soderquis B, Andren O. Frequency and typing of propionibacterium acnes in prostate tissue obtained from men with and without prostate cancer. Infect Agent Cancer. 2016;11:26.

[93] Palmieri B, Vadala M, Roncati L, Garelli A, Scandone F, Bondi M, Cermelli C. The long-standing history of corynebacterium parvum, immunity, and viruses. J Med Virol. 2020;92:2429-39.

[94] Fischer N, Mak TN, Shinohara DB, Sfanos KS, Meyer TF, Bruggemann H. Deciphering the intracellular fate of propionibacterium acnes in macrophages. Biomed Res Int. 2013;2013:603046.

[95] Jaamaa S, Laiho M. Maintenance of genomic integrity after DNA double strand breaks in the human prostate and seminal vesicle epithelium: The best and the worst. Mol Oncol. 2012;6:473-83.

[96] Grande G, Milardi D, Baroni S, Luca G, Pontecorvi A. Identification of seminal markers of male accessory gland inflammation: From molecules to proteome. Am J Reprod Immunol. 2018;80:e12992.

[97] Gong M, Wang F, Liu W, Chen R, Wu H, Zhang W, Yu X, Han R, Liu A, Chen Y, Han D. Pattern recognition receptormediated innate immune responses in seminal vesicle epithelial cell and their impacts on cellular functiondagger. Biol Reprod. 2019;101:733-47.

[98] Minas TZ, Tang W, Smith CJ, Onabajo OO, Obajemu A, Dorsey TH, Jordan SV, Obadi OM, Ryan BM, ProkuninaOlsson L, Loffredo CA, Ambs S. Ifnl4-deltag is associated with prostate cancer among men at increased risk of sexually transmitted infections. Commun Biol. 2018;1:191.

[99] Zhou H, Mohlenberg M, Terczynska-Dyla E, Winther KG, Hansen NH, Vad-Nielsen J, Laloli L, Dijkman R, Nielsen $\mathrm{AL}, \mathrm{Gad} \mathrm{HH}$, Hartmann R. The ifnl4 gene is a noncanonical interferon gene with a unique but evolutionarily conserved regulation. J Virol. 2020;94:e0153-19.

[100] Harrison IP, Vinh A, Johnson IRD, Luong R, Drummond GR, Sobey CG, Tiganis T, Williams ED, JJ OL, Brooks DA, Selemidis S. Nox2 oxidase expressed in endosomes promotes cell proliferation and prostate tumour development. Oncotarget. 2018;9:35378-93.

[101] Lin YM, Chu PH, Ouyang P. Tsg101 interacts with the androgen receptor and attenuates its expression through the endosome/lysosome pathway. Biochem Biophys Res Commun. 2018;503:157-64.

[102] Greulich BM, Plotnik JP, Jerde TJ, Hollenhorst PC. Toll-like receptor 4 signaling activates erg function in prostate cancer and provides a therapeutic target. NAR Cancer. 2021;3:zcaa046.

[103] Hermans KG, van Marion R, van Dekken H, Jenster G, van Weerden WM, Trapman J. Tmprss2:Erg fusion by translocation or interstitial deletion is highly relevant in androgen-dependent prostate cancer, but is bypassed in late-stage androgen receptor-negative prostate cancer. Cancer Res. 2006;66:10658-63.

[104] Tomlins SA, Laxman B, Varambally S, Cao X, Yu J, Helgeson BE, Cao Q, Prensner JR, Rubin MA, Shah RB, Mehra R, Chinnaiyan AM. Role of the tmprss2-erg gene fusion in prostate cancer. Neoplasia. 2008;10:177-88.

[105] Yoshimoto M, Joshua AM, Chilton-Macneill S, Bayani J, Selvarajah S, Evans AJ, Zielenska M, Squire JA. Threecolor fish analysis of tmprss $2 /$ erg fusions in prostate cancer indicates that genomic microdeletion of chromosome 21 is associated with rearrangement. Neoplasia. 2006;8:465-9.

[106] Linn DE, Penney KL, Bronson RT, Mucci LA, Li Z. Deletion of interstitial genes between tmprss 2 and erg promotes prostate cancer progression. Cancer Res. 2016;76:1869-81.

[107] Mehra R, Tomlins SA, Yu J, Cao X, Wang L, Menon A, Rubin MA, Pienta KJ, Shah RB, Chinnaiyan AM. Characterization of tmprss2-ets gene aberrations in androgen-independent metastatic prostate cancer. Cancer Res. 2008;68:3584-90. 
[108] Mwamukonda K, Chen Y, Ravindranath L, Furusato B, Hu Y, Sterbis J, Osborn D, Rosner I, Sesterhenn IA, McLeod DG, Srivastava S, Petrovics G. Quantitative expression of tmprss2 transcript in prostate tumor cells reflects tmprss2-erg fusion status. Prostate Cancer Prostatic Dis. 2010;13:47-51.

[109] Mukai S, Yamasaki K, Fujii M, Nagai T, Terada N, Kataoka H, Kamoto T. Dysregulation of type ii transmembrane serine proteases and ligand-dependent activation of met in urological cancers. Int J Mol Sci. 2020;21:2663.

[110] Adamo P, Ladomery MR. The oncogene erg: A key factor in prostate cancer. Oncogene. 2016;35:403-14.

[111] Mani RS, Amin MA, Li X, Kalyana-Sundaram S, Veeneman BA, Wang L, Ghosh A, Aslam A, Ramanand SG, Rabquer BJ, Kimura W, Tran M, Cao X, Roychowdhury S, Dhanasekaran SM, Palanisamy N, Sadek HA, Kapur P, Koch AE, Chinnaiyan AM. Inflammation-induced oxidative stress mediates gene fusion formation in prostate cancer. Cell Rep. 2016;17:2620-31.

[112] Mohamed AA, Tan SH, Sun C, Shaheduzzaman S, Hu Y, Petrovics G, Chen Y, Sesterhenn IA, Li H, Sreenath T, McLeod DG, Dobi A, Srivastava S. Erg oncogene modulates prostaglandin signaling in prostate cancer cells. Cancer Biol Ther. 2011;11:410-7.

[113] Burdova A, Rulisek P, Bouchal J, Kral M, Student V, Kolar Z. Infiltration of prostate cancer by cd204+and cd3+cells correlates with erg expression and tmprss2-erg gene fusion. Klin Onkol. 2018;31:421-8.

[114] Thangapazham R, Saenz F, Katta S, Mohamed AA, Tan SH, Petrovics G, Srivastava S, Dobi A. Loss of the nkx3.1 tumorsuppressor promotes the tmprss2-erg fusion gene expression in prostate cancer. BMC Cancer. 2014; 14:16.

[115] Powell K, Semaan L, Conley-LaComb MK, Asangani I, Wu YM, Ginsburg KB, Williams J, Squire JA, Maddipati $\mathrm{KR}$, Cher ML, Chinni SR. Erg/akr1c3/ar constitutes a feed-forward loop for ar signaling in prostate cancer cells. Clin Cancer Res. 2015;21:2569-79.

[116] Kaikkonen S, Paakinaho V, Sutinen P, Levonen AL, Palvimo JJ. Prostaglandin 15d-pgj(2) inhibits androgen receptor signaling in prostate cancer cells. Mol Endocrinol. 2013;27:212-23.

[117] Wright JL, Chery L, Holt S, Lin DW, Luedeke M, Rinckleb AE, Maier C, Stanford JL. Aspirin and nsaid use in association with molecular subtypes of prostate cancer defined by tmprss2:Erg fusion status. Prostate Cancer Prostatic Dis. 2016;19:53-56.

[118] Shan L, Ji T, Su X, Shao Q, Du T, Zhang S. Tmprss2-erg fusion promotes recruitment of regulatory t cells and tumor growth in prostate cancer. Am J Med Sci. 2018;356:72-8.

[119] Jiang J, Li J, Yunxia Z, Zhu H, Liu J, Pumill C. The role of prostatitis in prostate cancer: Meta-analysis. PLoS One. 2013;8:e85179.

[120] Han IH, Kim JH, Jang KS, Ryu JS. Inflammatory mediators of prostate epithelial cells stimulated with trichomonas vaginalis promote proliferative and invasive properties of prostate cancer cells. Prostate. 2019;79:1133-46.

[121] Adamo P, Porazinski S, Rajatileka S, Jumbe S, Hagen R, Cheung MK, Wilson I, Ladomery MR. The oncogenic transcription factor erg represses the transcription of the tumour suppressor gene pten in prostate cancer cells. Oncol Lett. 2017;14:5605-610.

[122] Attard G, Swennenhuis JF, Olmos D, Reid AH, Vickers E, A'Hern R, Levink R, Coumans F, Moreira J, Riisnaes R, Oommen NB, Hawche G, Jameson C, Thompson E, Sipkema R, Carden CP, Parker C, Dearnaley D, Kaye SB, Cooper CS, Molina A, Cox ME, Terstappen LW, de Bono JS. Characterization of erg, ar and pten gene status in circulating tumor cells from patients with castration-resistant prostate cancer. Cancer Res. 2009;69:2912-18.

[123] Haney NM, Faisal FA, Lu J, Guedes LB, Reuter VE, Scher HI, Eastham JA, Marchionni L, Joshu C, Gopalan A, Lotan TL. Pten loss with erg negative status is associated with lethal disease after radical prostatectomy. $J$ Urol. 2020;203:344-50.

[124] Shankar E, Vykhovanets EV, Vykhovanets OV, Maclennan GT, Singh R, Bhaskaran N, Shukla S, Gupta S. Highfat diet activates pro-inflammatory response in the prostate through association of stat-3 and nf-kappab. Prostate. 2012;72:233-43.

[125] Hayashi T, Fujita K, Nojima S, Hayashi Y, Nakano K, Ishizuya Y, Wang C, Yamamoto Y, Kinouchi T, Matsuzaki K, Jingushi K, Kato T, Kawashima A, Nagahara A, Ujike T, Uemura M, Pena M, Gordetsky JB, Morii E, Tsujikawa K, Netto GJ, Nonomura N. High-fat diet-induced inflammation accelerates prostate cancer growth via il6 signaling. Clin Cancer Res. 2018;24:4309-18.

[126] Wang H, Sun X, J LV, Kon ND, Ferrario CM, Groban L. Estrogen receptors are linked to angiotensin-converting enzyme 2 (ace2), adam metallopeptidase domain 17 (adam-17), and transmembrane protease serine 2 (tmprss2) expression in the human atrium: Insights into covid-19. Hypertens Res. 2021;44:882-84.

[127] Bonkhoff H. Estrogen receptor signaling in prostate cancer: Implications for carcinogenesis and tumor progression. Prostate. 2018;78:2-10. 
[128] Shaw GL, Whitaker H, Corcoran M, Dunning MJ, Luxton H, Kay J, Massie CE, Miller JL, Lamb AD, Ross-Adams H, Russell R, Nelson AW, Eldridge MD, Lynch AG, Ramos-Montoya A, Mills IG, Taylor AE, Arlt W, Shah N, Warren AY, Neal DE. The early effects of rapid androgen deprivation on human prostate cancer. Eur Urol. 2016;70:214-8.

[129] Kim H, Datta A, Talwar S, Saleem SN, Mondal D, Abdel-Mageed AB. Estradiol-erbeta2 signaling axis confers growth and migration of crpc cells through tmprss2-etv5 gene fusion. Oncotarget. 2017;8:62820-833.

[130] Zammarchi F, Boutsalis G, Cartegni L. 5' utr control of native erg and of tmprss2:Erg variants activity in prostate cancer. PLoS One. 2013;8:e49721.

[131] Lee RS, Zhang L, Berger A, Lawrence MG, Song J, Niranjan B, Davies RG, Lister NL, Sandhu SK, Rubin MA, Risbridger GP, Taylor RA, Rickman DS, Horvath LG, Daly RJ. Characterization of the erg-regulated kinome in prostate cancer identifies tnik as a potential therapeutic target. Neoplasia. 2019;21:389-400.

[132] Mohamed AA, Xavier CP, Sukumar G, Tan SH, Ravindranath L, Seraj N, Kumar V, Sreenath T, McLeod DG, Petrovics G, Rosner IL, Srivastava M, Strovel J, Malhotra SV, LaRonde NA, Dobi A, Dalgard CL, Srivastava S. Identification of a small molecule that selectively inhibits erg-positive cancer cell growth. Cancer Res. 2018;78:3659-3671.

[133] Bi X, He H, Ye Y, Dai Q, Han Z, Liang Y, Zhong W. Association of tmprss2 and klk11 gene expression levels with clinical progression of human prostate cancer. Med Oncol. 2010;27:145-51.

[134] Vaarala MH, Porvari K, Kyllonen A, Lukkarinen O, Vihko P. The tmprss2 gene encoding transmembrane serine protease is overexpressed in a majority of prostate cancer patients: Detection of mutated tmprss 2 form in a case of aggressive disease. Int J Cancer. 2001;94:705-10.

[135] Vaarala MH, Porvari K, Kyllonen A, Vihko P. Differentially expressed genes in two lncap prostate cancer cell lines reflecting changes during prostate cancer progression. Lab Invest. 2000;80:1259-68.

[136] Katopodis P, Anikin V, Randeva HS, Spandidos DA, Chatha K, Kyrou I, Karteris E. Pancancer analysis of transmembrane protease serine 2 and cathepsin 1 that mediate cellular sarscov2 infection leading to covid-19. Int J Oncol. 2020;57:533-9.

[137] Chai P, Yu J, Ge S, Jia R, Fan X. Genetic alteration, rna expression, and DNA methylation profiling of coronavirus disease 2019 (covid-19) receptor ace2 in malignancies: A pan-cancer analysis. J Hematol Oncol. 2020;13:43.

[138] Zhang Q, Lu S, Li T, Yu L, Zhang Y, Zeng H, Qian X, Bi J, Lin Y. Ace2 inhibits breast cancer angiogenesis via suppressing the vegfa/vegfr2/erk pathway. J Exp Clin Cancer Res. 2019;38:173.

[139] Teng DH, Chen Y, Lian L, Ha PC, Tavtigian SV, Wong AK. Mutation analyses of 268 candidate genes in human tumor cell lines. Genomics. 2001;74:352-64.

[140] Nickerson ML, Im KM, Misner KJ, Tan W, Lou H, Gold B, Wells DW, Bravo HC, Fredrikson KM, Harkins TT, Milos P, Zbar B, Linehan WM, Yeager M, Andresson T, Dean M, Bova GS. Somatic alterations contributing to metastasis of a castration-resistant prostate cancer. Hum Mutat. 2013;34:1231-41.

[141] Zhao Y, Epstein RJ. Unexpected functional similarities between gatekeeper tumour suppressor genes and protooncogenes revealed by systems biology. J Hum Genet. 2011;56:369-76.

[142] Vogelstein B, Kinzler KW. Cancer genes and the pathways they control. Nat Med. 2004;10:789-99.

[143] Ko CJ, Hsu TW, Wu SR, Lan SW, Hsiao TF, Lin HY, Lin HH, Tu HF, Lee CF, Huang CC, Chen MM, Hsiao PW, Huang HP, Lee MS. Inhibition of tmprss 2 by hai-2 reduces prostate cancer cell invasion and metastasis. Oncogene. 2020;39:5950-63.

[144] Wu SR, Lin CH, Shih HP, Ko CJ, Lin HY, Lan SW, Lin HH, Tu HF, Ho CC, Huang HP, Lee MS. Hai-2 as a novel inhibitor of plasmin represses lung cancer cell invasion and metastasis. Br J Cancer. 2019;120:499-511.

[145] Martin SK, Kyprianou N. Gene fusions find an erg-way to tumor inflammation. Cancer Biol Ther. 2011;11:418-20.

[146] Zhao Y, Epstein RJ. Programmed genetic instability: A tumor-permissive mechanism for maintaining the evolvability of higher species through methylation-dependent mutation of DNA repair genes in the male germ line. Mol Biol Evol. 2008;25:1737-49.

[147] Rostad K, Mannelqvist M, Halvorsen OJ, Oyan AM, Bo TH, Stordrange L, Olsen S, Haukaas SA, Lin B, Hood L, Jonassen I, Akslen LA, Kalland KH. Erg upregulation and related ets transcription factors in prostate cancer. Int J Oncol. 2007;30:19-32.

[148] Merz C, von Massenhausen A, Queisser A, Vogel W, Andren O, Kirfel J, Duensing S, Perner S, Nowak M. Il-6 overexpression in erg-positive prostate cancer is mediated by prostaglandin receptor ep2. Am J Pathol. 2016;186: 974-84.

[149] Shirato K, Kawase M, Matsuyama S. Wild-type human coronaviruses prefer cell-surface tmprss2 to endosomal cathepsins for cell entry. Virology. 2018;517:9-15.

[150] Miyake M, Ohnishi K, Hori S, Nakano A, Nakano R, Yano H, Ohnishi S, Owari T, Morizawa Y, Itami Y, Nakai Y, Inoue T, Anai S, Torimoto K, Tanaka N, Fujii T, Furuya H, Rosser CJ, Fujimoto K. Mycoplasma genitalium infection and chronic inflammation in human prostate cancer: Detection using prostatectomy and needle biopsy specimens. Cells. 2019;8:212. 
[151] Ashok A, Keener R, Rubenstein M, Stookey S, Bajpai S, Hicks J, Alme AK, Drake CG, Zheng Q, Trabzonlu L, Yegnasubramanian S, De Marzo AM, Bieberich CJ. Consequences of interleukin 1beta-triggered chronic inflammation in the mouse prostate gland: Altered architecture associated with prolonged cd4(+) infiltration mimics human proliferative inflammatory atrophy. Prostate. 2019;79:732-45.

[152] Wu YM, Cieslik M, Lonigro RJ, Vats P, Reimers MA, Cao X, Ning Y, Wang L, Kunju LP, de Sarkar N, Heath EI, Chou J, Feng FY, Nelson PS, de Bono JS, Zou W, Montgomery B, Alva A, Team PSCIPCD, Robinson DR, Chinnaiyan AM. Inactivation of cdk12 delineates a distinct immunogenic class of advanced prostate cancer. Cell. 2018;173:1770-1782 e1714. 